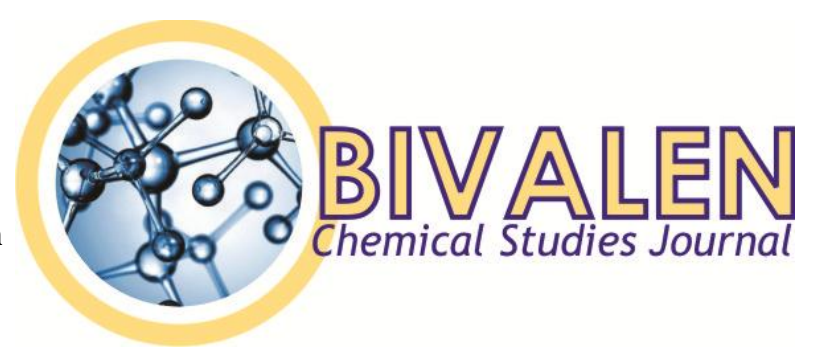

\title{
AKTIVITAS ANTIOKSIDAN BUAH DOYO
}

ANTIOXIDANT ACTIVITY OF DOYO FRUITS

\author{
Irsalinda Wessa Nurrahim $^{1}$, Muhammad Ismail Marzuki ${ }^{{ }^{*}}$, Sukemi ${ }^{12^{*}}$ \\ ${ }^{I}$ SMA Negeri 2 Samarinda, Kalimantan Timur, Indonesia \\ ${ }^{2}$ Program Studi Sarjana Pendidikan Kimia, Fakultas Keguruan dan Ilmu Pendidikan, Universitas Mulawarman, \\ Samarinda, Kalimantan Timur, Indonesia \\ *Corresponding Author: mhmmdismail1901@gmail.com, kekem.basri@gmail.com
}

\begin{abstract}
ABSTRAK
Tujuan penelitian ini adalah untuk mengetahui aktivitas antioksidan buah doyo (Curculigo latifolia sp.) dan kandungan senyawa metabolit sekundernya. Sampel dalam penelitian ini adalah buah, daging buah dan kulit buah doyo. Kurang lebih 2,5 g sampel diblender dalam 100 $\mathrm{ml}$ aquades selama 1 menit dan disaring. Hasil saringan dimasukkan ke dalam labu takar $200 \mathrm{ml}$ dan diencerkan hingga tanda batas. Uji aktivitas antioksidan menggunakan metode DPPH (1,1Diphenyl-2-picryl Hidrazil) dan uji senyawa metabolit sekunder menggunakan uji warna. Hasil penelitian menunjukkan aktivitas antioksidan buah, daging buah dan kulit buah doyo secara berturut-turut adalah $85,91 \pm 0,99 \% ; 87,89 \pm 1,97 \%$; dan $85,32 \pm 2,13 \%$. Ekstrak aquades buah doyo mengandung alkaloid dan terpenoid. Penelitian ini menunjukkan bahwa buah doyo berfungsi sebagai antioksidan.
\end{abstract}

\section{Kata kunci : antioksidan, doyo, Curculigo latifolia sp., DPPH}

\begin{abstract}
Goal of this study was to know antioxidant activity of doyo (Curculigo latifolia sp.) fruits and its secondary metabolite compounds. Samples were doyo fruit, flesh of fruit and peel of fruit of doyo. Approximately $2.5 \mathrm{~g}$ of sample was mashed using commecrcial blenderin $100 \mathrm{ml}$ of distilled water for 1 minute and followed by filtartion. Filtrat was added by distilled water up to $200 \mathrm{ml}$ in volumetric flask. Antioxidant activity assay was analyzed using DPPH (1,1-Diphenyl2-picryl Hidrazil) method and secondary metabolite compound was tested using color method. The results showed that the antioxidant activity of fruit, flesh of fruit, and peel of fruit of doyo were $85.91 \pm 0.99 \% ; 87.89 \pm 1.97 \%$; dan $85.32 \pm 2.13 \%$, respectively. The aqueous extract of doyo fruit contained alkaloid and terpenoid. This research showed that the doyo fruit plays an antioxidant agent.
\end{abstract}

Keywords: antioxidant, doyo, Curculigo latifolia sp., DPPH 


\section{PENDAHULUAN}

Antioksidan dan radikal bebas merupakan istilah yang sering dibahas dan diteliti dalam dunia kesehatan. Radikal bebas bersifat tidak stabil dan sangat reaktif yakni cenderung bereaksi dengan molekul lainnya untuk mencapai kestabilan. Radikal dengan kereaktifan yang tinggi ini dapat memulai sebuah reaksi berantai dalam sekali pembentukannya sehingga menimbulkan senyawa yang tidak normal dan memulai reaksi berantai yang dapat merusak selsel penting dalam tubuh (Badarinath, dkk. 2010). Radikal bebas diatasi dengan penggunaan antioksidan (Mandal, dkk. 2009).

Antioksidan adalah molekul yang mampu menghambat oksidasi dari molekul oksidan. Oksidasi merupakan reaksi kimia yang memindahkan elektron dari satu subtansi ke agen oksidan (Ardhie 2011). Berdasarkan sumbernya, antioksidan dapat dibagi menjadi 2 yaitu antioksidan sintetik dan alami. Antioksidan sintetik merupakan senyawa yang disintesis secara kimia seperti butil hidroksi anisol (BHA), butil hidroksi toluen (BHT), propil galat, tert-butil hidroksi quinon (TBHQ), dan tokoferol. Antioksidan alami merupakan senyawa antioksidan yang terdapat secara alami dalam tubuh sebagai mekanisme pertahanan tubuh normal maupun berasal dari asupan luar tubuh. Sumber antioksidan alami adalah buah-buahan, sayursayuran, dan bagian tumbuh-tumbuhan lainnya. Salah satu sumber senyawa antioksidan adalah tanaman dengan kandungan senyawa polifenol yang tinggi (Trisantini, dkk. 2016).

Tanaman doyo (Curculigo latifolia sp.) merupakan tumbuhan semak, dengan daur hidup parenial, yang banyak terdapat pada daerah Kalimantan Timur. Pada umumnya, tumbuhan doyo dimanfaatkan masyarakat sekitar sebagai bahan dasar kain tenunan tradisional. Tanaman doyo memiliki kandungan serat sebanyak $40-55 \%$ dari berat segar tanaman. Tanaman doyo juga merupakan tanaman yang kaya akan antioksidan dan mengandung protein yang disebut curculin. Curculin merupakan satu-satunya protein yang berasa manis (Monda 2015).

Penelitian tentang antioksidan buah, kulit buah dan daging buah doyo belum pernah dilaporkan. Berdasarkan uraian di atas, penelitian ini dirancang untuk mengetahui aktivitas antioksidan buah, daging buah dan kulit buah doyo.

\section{METODE PENELITIAN}

\section{Bahan}

Sampel buah doyo dibeli dari warga di Kota Tenggarong Kalimantan Timur pada tanggal 15 Agustus 2019. Bahan kimia yang digunakan dalam penelitian ini adalah aquades yang diproduksi oleh Laboratorium Kimia FKIP Universitas Mulawarman, metanol (teknis), DPPH, asetat anhidrat, amoniak, asam klorida, asam sulfat, bismut nitrat, besi (III) klorida, raksa (II) klorida, kalium iodida, kloroform, methanol, natrium sulfat anhidrat, iodium, dan magnesium (Merck dan Sigma Aldrich).

\section{Persiapan sampel}

Buah doyo segar dicuci bersih dengan air kran, dibilas dengan aquades dan ditiriskan. Sebagian buah doyo yang bersih dipisahkan antara daging buah dengan kulitnya. Sempel buah, kulit buah dan daging doyo ( $\pm 2,5$ gram) dihaluskan dengan blender dalam $100 \mathrm{ml}$ aquades selama 1 menit dan disaring menggunakan penyaring yang terhubung dengan pompa vakum. Ke dalam filtrat ditambahkan aquades hingga volume $200 \mathrm{ml}$ menggunakan labu takar dan dihimogenkan. Masing-masing sampel dilakukan 2 kali pengulangan.

\section{Uji Fitokimia}

Uji fitokimia dilakukan pada sampel buah doyo. Uji fitokimia dilakukan menggunakan metode uji warna (Sukemi, dkk. 2015).

\section{Pengujian aktifitas antioksidan}

Pengujian antioksidan dengan metode DPPH dilakukan sesuai metode Sukemi, dkk. (2015) dengan beberapa modifikasi. Sebanyak $1 \mathrm{ml}$ setiap sampel yang diuji dicampur dengan 1,0 ml larutan metanol DPPH $0,1 \mathrm{mM}$. Tingkat berkurangnya warna dari larutan menunjukkan efisiensi penangkap radikal DPPH. Absorbansi dibaca dengan spektrofotometer UV-Vis pada $\lambda 517 \mathrm{~nm}$ terhadap blanko setelah diinkubasi selama 30 menit. Persentase aktivitas penangkapan radikal DPPH dihitung sebagai SA $(\%)=[1-((\mathrm{A} 1-\mathrm{A} 2) / \mathrm{A} 0)] \mathrm{x}$ $100 \%$, dimana A0 adalah absorbansi kontrol yaitu absorbansilarutan DPPH tanpa sampel yang diuji, A1 adalah absorbansi campuran DPPH dengan sampel yang diuji, dan A2 adalah absorbansi larutan sampel tanpa larutan DPPH. 


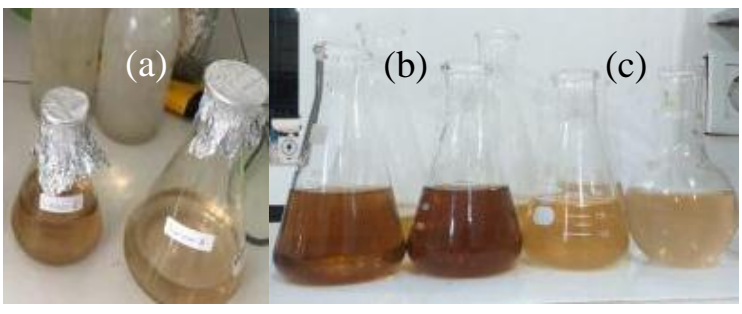

Gambar 1. Larutan aquades (a) buah, (b) daging buah dan (c) kulit buah doyo.

Tabel 1

Ativitas antioksidan larutan aquades buah, daging buah dan kulit buah doyo

\begin{tabular}{lc}
\hline Senyawa metabolit sekunder & Hasil uji \\
\hline Alkoloid & + \\
Antrokuinon & - \\
Antrosianin & - \\
Fenolik & - \\
Flavanoid & - \\
kardiak glikosida & - \\
Saponin & - \\
Tanin & - \\
Terpenoid & + \\
\hline
\end{tabular}

Tabel 2

Ativitas antioksidan larutan aquades buah, daging buah dan kulit buah doyo

\begin{tabular}{lc}
\hline \multicolumn{1}{c}{ Sampel } & \multicolumn{1}{c}{$\begin{array}{c}\text { Aktivitas } \\
\text { antioksidan }(\%)\end{array}$} \\
\hline $\begin{array}{l}\text { Larutan aquades buah } \\
\text { doyo }\end{array}$ & $85,906 \pm 0,99$ \\
$\begin{array}{l}\text { Larutan aquades daging } \\
\text { buah doyo }\end{array}$ & $85,324 \pm 1,97$ \\
$\begin{array}{l}\text { Larutan aquades kulit buah } \\
\text { doyo }\end{array}$ & $87,891 \pm 2,13$ \\
\hline
\end{tabular}

\section{HASIL DAN PEMBAHASAN}

Larutan aquades buah, daging buah dan kulit buah doyo berwarna kuning - cokelat (Gambar 1). Senyawa metabolit sekunder dalam larutan aquades buah doyo adalah alkoloid dan terpenoid (Tabel 1). Aktivitas antioksidan buah, daging buah dan kulit buah doyo disajikan dalam Tabel 2 .

Berdasarkan data pada Tabel 2, larutan aquades buah, daging buah, daging dan kulit buah doyo memiliki aktifitas antioksidan. Ketiga sampel tersebut memiliki aktivitas antioksidan yang tinggi dalam menangkap radikal DPPH dengan aktivitas penangkapan radikal sebesar $85,91 \pm 0,99 \%$ untuk larutan aquades buah doyo, 85,32 $\pm 2,13 \%$ untuk larutan aquades daging buah doyo dan $87,89 \pm 1,97 \%$ untuk larutan aquades kulit buah doyo. Aktivitas antioksidan ketiga larutan sampel dimungkinkan akibat adanya senyawa alkaloid dan terpenoid. Terpenoid dan alkaloid berperan dalam aktivitas antioxidan (Grabmann 2005, Tiong, dkk. 2013).

\section{SIMPULAN}

Penelitian ini menunjukkan bahwa buah doyo merupakan suber antioqsidan yang baik untuk menangkap radikal bebas.

\section{UCAPAN TERIMAKASIH}

Penulis mengucapkan terimakasih kepada kepala SMA Negeri 2 Samarinda atas pembiyaan penelitian ini dan kepala Laboratorium Kimia Fakultas Keguruan dan Ilmu Pendidikan Universitas Mulawarman yang telah memberikan izin penulis melakukan penelitian.

\section{DAFTAR PUSTAKA}

Ardhie, A.M. 2011. Radikal bebas dan peran antioksidan dalam mencegah penuaan. Sceintific Journal of Pharmaceutical Development and Medical Application, 24(1), 1-6.

Badarinath, A.V., Rao, K.M., Chetty, C.M.S, Ramkanth, S., Rajan, T.V.S., Gnanaprakash, K. 2010. A review onin-vitro antioxidant methods: comparisions, correlations and considerations, International Journal of PharmTech Research, 2(2), 1276-1285.

Grabmann, J. 2005. Terpenoids as plant antioxidants, Vitamins \& Hormones, 72, 505535.

Mandal, S., Yadav, S., Yadav, S., Nema, R.K. 2009. Antioxidants: a review, Journal of Chemical and Pharmaceutical Research, 1(1), 102-104.

Monda. 20015. Ulap doyo, wastra dan obat herbal alternatif (Online), https://www.mondasiregar. com/ulap-doyo-wastra-dan-obat-herbalalternatif/

Sukemi, Khownium, K., Arung, E.T.K, Kusuma, I.W., Mingvanish, W. 2015. Antioxidant activities of crude methanolic exract of Nephelium ramboutan-ake (Labill.) Leenh. Peel, Pure and Applied Chemistry International Conference 2015 (PACCON2015) Proceeding, 123-127. 
Tiong, S.H., Looi, C.Y., Hazni, H., Aditya, A., Paydar, M., Wong, W.F., Cheah, S., Mustofa, M.R., and Awang, K. 2013. Antidiabetic and antioxidant properties of alkaloids from Catharantus roseus (L.) G. Don, Molecules, 18(8), 9770-9784.

Tristantini, D., Ismawati, A., Pradana, B.T., Jonathan, J.G., 2016, Pengujian aktivitas antioksidan menggunakan metode DPPH pada daun tanjung (Mimusops elegi L.) dalam Prosiding Seminar Nasional Teknik Kimia "Kejuangan", 1-7. 